\title{
Challenges for the therapeutic use of pluripotent stem derived cells
}

\author{
Magda Forsberg ${ }^{1}$ and Outi Hovatta ${ }^{2}$ \\ ${ }^{1}$ Department of Medical Biochemistry and Biophysics, Karolinska Institutet, Stockholm, Sweden \\ ${ }^{2}$ Department of Clinical Science, Intervention and Technology, Karolinska Institutet, Stockholm, Sweden
}

Edited by:

Anis Feki, Geneva University

Hospitals, Switzerland

Reviewed by:

Yuji Mishina, University of Michigan, USA

Liang Ma, Washington University, USA

${ }^{*}$ Correspondence:

Outi Hovatta, Department of Clinical

Science, Intervention and Technology, H9 K 54, Karolinska

Universitetssjukhuset, 14186

Stockholm, Sweden.

e-mail: outi.hovatta@ki.se
Human embryonic stem cells (hESC) and induced pluripotent stem cells (hiPSC) are an attractive cell source for regenerative medicine. These cells can be expanded to vast numbers and can be differentiated to many desired pluripotent stem cells (PSC) derived therapeutic cells. Cell replacement bears promises, but also challenges. The introduction of exogenous cells in a recipient must address several different topics; its safety, the exclusion of tumor formation, the immunological response and possible rejection, the cells cleanliness and their biological quality, and quantity representing the functionality of the PSC derived therapeutic cells. Tumor formation requires the removal of any PSC remaining after differentiation. Immunological rejection can be addressed with immunomodulation of the cells and the recipient. Cleanliness can be optimized using good manufacturing practice quality systems. At last, the functionality of the cells must be tested in in vitro and in animal models. After addressing these challenges, precise strategies are developed to monitor the status of the cells at different times and in case of undesired results, corresponding counteracting strategies must exist before any clinical attempt.

Keywords: cell transplantation, human embryonic stem cells, human pluripotent stem cells, GMP, immunoreactivity, tumorigenic

\section{CULTURE CONDITIONS OF PLURIPOTENT CELLS}

After initial establishment and derivation of human embryonic stem cells (hESC; Thomson et al., 1998; Reubinoff et al., 2000) their potential therapeutic use in cell replacement strategies was clear. Before cell transplantation, several steps must be fulfilled. First the infection free status of the donors has to be addressed, In Europe couples are tested before any fertility treatment is offered, but the cells themselves have to be tested, too (Hovatta, 2011). Second, optimized good manufacturing practice (GMP) compliant systems must be implemented for derivation, scaling-up, banking of cells, and their corresponding quality assurance controls (Unger et al., 2008; Ausubel et al., 2011). The culture systems currently encounter the problem of suboptimal quality of xenofree culture constituents. Thus strategies are needed to overcome this difficulty (Sidhu et al., 2008). Steps have been taken; initially, hESC were grown on irradiated mouse feeders, later human foreskin fibroblast were used (Hovatta et al., 2003), now we can use GMP compliant coating substrates specially designed for hESC growth (Rodin et al., 2010). Steps were also taken for the generation defined xeno-free GMP compliant medium for derivation and for expansion (Ludwig et al., 2006; Rajala et al., 2010; Ilic et al., 2012).

\section{REPROGRAMMING AND hIPSC}

The potential of somatic cell reprogramming via expression of specific transcription factors and thus the generation of hESC induced pluripotent stem cells (hiPSC; Takahashi and Yamanaka, 2006; Takahashi et al., 2007) has the advantage that they could be generated from the recipient patients own cells. This could overcome an allogenic immune rejection (Li and Zhong, 2009). But this potential although tempting, has not been proven. There is no deep understanding of the effects that the reprogramming events have; for instance on extracellular signaling (Okita et al., 2011), and the way that this could lead to immune reaction. It was shown that specific $\mathrm{T}$ cells were reactive toward Oct- 4 antigens. Hence fast reactivity is already present in healthy individuals for controlling any rapidly amplifying cells (Dhodapkar et al., 2010). Un-silenced expression of the reprogramming factor Oct- 4 might then cause undesired immunoreactivity on the transplanted cells. Immunoreactivity toward graft-derived hiPSC of the same genetic background was also shown in animal models (Zhao et al., 2011).

For successful reprogramming of somatic cells, many epigenetic changes must occur in an adequate manner. Failure will result in abnormal phenotypes (Mikkelsen et al., 2008). DNA methylation changes during reprogramming must occur in important developmental and oncogenic regions, which increases the oncogenic risk of the reprogrammed cells (Doi et al., 2009; Ohm et al., 2010). There is an additional risk for abnormalities and high tumorigenic potential, especially if c-myc is used as one of the transcription factors (Okita et al., 2007). Also, genetic and epigenetic stability and large-scale genomic rearrangements after reprogramming and subsequent culture (Kim et al., 2010; Gore et al., 2011; Hussein et al., 2011; Lister et al., 2011) might challenge the application of hiPSC under a clinical cell replacement therapy. Further studies to clarify these issues are needed (Pera, 2011). It is also important to address the safety of long-term culture, as shown recently; the occurrence of chromosomal rearrangements in long-term culture of $125 \mathrm{hESC}$ and 11 hiPSC (Amps et al., 2011). 


\section{PLURIPOTENT STEM CELL DIFFERENTIATION}

There is a consensus that undifferentiated pluripotent stem cells (PSC) will not be used directly in any clinical transplantations procedure, but instead their PSC derived differentiated cells Recently, results using hESC derived dopaminergic neurons have shown correct phenotype differentiation and grafting potential given by no tumor formation, maintenance of the grafted cells, and functional recovery in parkinsonian animal models in mice, rats, and monkeys (Kriks et al., 2011). The protocols designed for this cell replacement assay were optimal regarding the phenotype, quantity of the cells, functionality, and immunological properties. Integration of transplanted cells was achieved when single cells were transplanted, the use of proper biodegradable scaffolds must also be considered. In addition to this initial report regarding the neural lineage, differentiation protocols for other cell types are needed.

Even if transplantation in animal models is successful, it is important to generate safety strategies before clinical trials to appropriately remove undifferentiated PSC from their PSC derived therapeutic cells. Strategies such as inserting suicide gene (Drobyski et al., 2003; Uchibori et al., 2009) might have controversial outcomes under clinical trials given their safety (Yi et al., 2011). Alternatively, strategies such as removal of undifferentiated cells using antibodies might be safer (Tang et al., 2011).

\section{THE IMMUNOGENIC PROFILES}

As discussed earlier, an optimal engraftment and cell replacement strategy should account for a minimal immune reaction in the recipient. This immune reaction occurs because the immune system of the recipient recognizes the grafted cells as foreign material or mismatched cellular components and thus generates a cascade of events that ultimately results in destruction and rejection of the grafted cells. This destruction can also compromise the recipient's immune status (Petersen et al., 1975). Immunoreactivity toward the graft is mainly caused by $\mathrm{T}$ cell response toward unmatched major histocompatibility complex (MHC); in humans called human leukocyte antigen (HLA). If the profile is unmatched, it will result in rejection (Lechler et al., 2005). This rejection can occur via direct allorecognition of the donor antigen presenting cells (APC) or via indirect recognition of apoptotic cells ingested by the recipients APC, in both cases APCs presenting unmatched MHCs (Walsh et al., 2004). Several groups have studied MHC profiles of hESC and their differentiated cells (Swijnenburg et al., 2008; Pearl et al., 2011). Findings are that undifferentiated cells express MHC I antigens, though at low levels compared with somatic cells; but they do not express MHC II molecules (Drukker et al., 2002, 2006; Li et al., 2004). During in vitro differentiation toward germ lineages, embryoid body (EB) formation, or teratoma formation MHC I expression increases dramatically (Drukker and Benvenisty, 2004). Also culture methods of hESC can change antigen expression levels (Rajala et al., 2010). Careful selection of culture conditions, both for the undifferentiated hESC and for their differentiated derivatives is needed.

\section{REFERENCES}

Amps, K., Andrews, P. W., Anyfantis, G., Armstrong, L., Avery, S., Baharvand, H., Baker, J., Baker, D., Munoz,
M. B., Beil, S., Benvenisty, N., BenYosef, D., Biancotti, J. C., Bosman, A., Brena, R. M., Brison, D., Caisander, G., Camarasa, M. V., Chen, J., Chiao,

Human embryonic stem cells adopts the expression of nonhuman cell surface markers if exposed to such substances during culture (Martin et al., 2005; Hisamatsu-Sakamoto et al., 2008). Hence, optimal culture conditions must be xeno-free from the initial derivation and onward. These culture conditions must be carefully analyzed and scientific consensus must be achieved in order to raise current methodologies.

\section{IMMUNOSUPPRESSION}

Challenges with the immunoreactivity of the transplantable cells could be addressed by rigorous immunosuppressive treatments. Unfortunately, this is not desired, since there is a clear correlation between the length and intensity of exposure to immunosuppressive therapy and post-transplant risk of malignancy and tumor aggressiveness (Gutierrez-Dalmau and Campistol, 2007). An interesting solution is costimulatory blockage of $\mathrm{T}$ cell response (Grinnemo et al., 2006, 2008; Swijnenburg et al., 2008; Pearl et al., 2011). This immunosuppression strategy will generate tolerance to the grafted cells and thus increase graft survival; initial pharmaceutical agents have been developed and pending clinical applications to the FDA are to give in the near future more information.

\section{DISCUSSION}

In this mini-review we highlighted the most important areas to be considered under a cell replacement therapy. The possibility of using hiPSC derived therapeutic cells in cell replacement therapies requires still long-term studies in non-human animal models addressing the questions of immunogenicity, epigenetic and genetic stability of these cells, and the optimized differentiation of the cells.

The importance of profiling immunogenic markers as part of the stem-ness characterization and profiling of cells allocated in stem cell banks must be consider. The allocation and custody of the characterization data is equally important. Such information has to be well protected so that it will not be lost in any given situation. Adequate culture conditions, supporting correct immunogenicity of the cells under a transplantation assay is also required.

Next, the management of immunosuppression schemes must aim to a minimal time influencing the immunological status of the recipient.

From all the information obtained, profiles can be generated before and after differentiation. These profiles can then be used in combination with methodologies focused at monitoring the status of the transplanted cells. In a given scenario that undesired cells persist in the transplant, adequate counteracting actions have immediately to be taken. Such possibilities have to be tested and the removal of undesired effects confirmed before starting cell transplantations. Failure in any particular cell replacement clinical trial will imply disastrous effects. Responsible decisions are needed under complete scrutiny from medical agencies and the scientific community.

E., Choi, Y. M., Choo, A. B., Collins,

D., Colman, A., Crook, J. M., Daley,

G. Q., Dalton, A., De Sousa, P. A.,

Denning, C., Downie, J., Dvorak, P.,
Montgomery, K. D., Feki, A., Ford, A., Fox, V., Fraga, A. M., Frumkin, T., Ge, L., Gokhale, P. J., Golan-Lev, T., Gourabi, H., Gropp, M., Guangxiu, 
L., Hampl, A., Harron, K., Healy, L., Herath, W., Holm, F., Hovatta, O., Hyllner, J., Inamdar, M. S., Irwanto, A. K., Ishii, T., Jaconi, M., Jin, Y., Kimber, S., Kiselev, S., Knowles, B. B., Kopper, O., Kukharenko, V., Kuliev, A., Lagarkova, M. A., Laird, P. W., Lako, M., Laslett, A. L., Lavon, N., Lee, D. R., Lee, J. E., Li, C., Lim, L. S., Ludwig, T. E., Ma, Y., Maltby, E., Mateizel, I., Mayshar, Y., Mileikovsky, M., Minger, S. L., Miyazaki, T., Moon, S. Y., Moore, H., Mummery, C., Nagy, A., Nakatsuji, N., Narwani, K., Oh, S. K., Oh, S. K., Olson, C., Otonkoski, T., Pan, F., Park, I. H., Pells, S., Pera, M. F., Pereira, L. V., Qi, O., Raj, G. S., Reubinoff, B., Robins, A., Robson, P., Rossant, J., Salekdeh, G. H., Schulz, T. C., Sermon, K., Sheik Mohamed, J., Shen, H., Sherrer, E., Sidhu, K., Sivarajah, S., Skottman, H., Spits, C., Stacey, G. N., Strehl, R., Strelchenko, N., Suemori, H., Sun, B., Suuronen, R., Takahashi, K., Tuuri, T., Venu, P., Verlinsky, Y., Ward-van Oostwaard, D., Weisenberger, D. J., Wu, Y., Yamanaka, S., Young, L., and Zhou, Q. (2011). Screening ethnically diverse human embryonic stem cells identifies a chromosome 20 minimal amplicon conferring growth advantage. Nat. Biotechnol. 29, 1132-1144.

Ausubel, L. J., Lopez, P. M., and Couture, L. A. (2011). GMP scale-up and banking of pluripotent stem cells for cellular therapy applications. Methods Mol. Biol. 767, 147-159.

Dhodapkar, K. M., Feldman, D., Matthews, P., Radfar, S., Pickering, R., Turkula, S., Zebroski, H., and Dhodapkar, M. V. (2010). Natural immunity to pluripotency antigen OCT4 in humans. Proc. Natl. Acad. Sci. U.S.A. 107, 8718-8723.

Doi, A., Park, I. H., Wen, B., Murakami, P., Aryee, M. J., Irizarry, R., Herb, B., Ladd-Acosta, C., Rho, J., Loewer, S., Miller, J., Schlaeger, T., Daley, G. Q., and Feinberg, A. P. (2009). Differential methylation of tissueand cancer-specific $\mathrm{CpG}$ island shores distinguishes human induced pluripotent stem cells, embryonic stem cells and fibroblasts. Nat. Genet. 41, 1350-1353.

Drobyski, W. R., Gendelman, M., Vodanovic-Jankovic, S., and Gorski, J. (2003). Elimination of leukemia in the absence of lethal graftversus-host disease after allogenic bone marrow transplantation. J. Immunol. 170, 3046-3053.

Drukker, M., and Benvenisty, N. (2004). The immunogenicity of human embryonic stem-derived cells. Trends Biotechnol. 22, 136-141.

Drukker, M., Katchman, H., Katz, G., Even-Tov Friedman, S., Shezen, E., Hornstein, E., Mandelboim, O., Reisner, Y., and Benvenisty, N. (2006) Human embryonic stem cells and their differentiated derivatives are less susceptible to immune rejection than adult cells. Stem Cells 24, 221-229.

Drukker, M., Katz, G., Urbach, A., Schuldiner, M., Markel, G., ItskovitzEldor, J., Reubinoff, B., Mandelboim, O., and Benvenisty, N. (2002). Characterization of the expression of MHC proteins in human embryonic stem cells. Proc. Natl. Acad. Sci. U.S.A. 99, 9864-9869.

Gore, A., Li, Z., Fung, H. L., Young, J. E., Agarwal, S., Antosiewicz-Bourget, J., Canto, I., Giorgetti, A., Israel, M. A., Kiskinis, E., Lee, J. H., Loh, Y. H., Manos, P. D., Montserrat, N., Panopoulos, A. D., Ruiz, S., Wilbert, M. L., Yu, J., Kirkness, E. F., Izpisua Belmonte, J. C., Rossi, D. J., Thomson, J. A., Eggan, K., Daley, G. Q., Goldstein, L. S., and Zhang, K. (2011). Somatic coding mutations in human induced pluripotent stem cells. Nature 471, 63-67.

Grinnemo, K. H., Genead, R., KumagaiBraesch, M., Andersson, A., Danielsson, C., Mansson-Broberg, A., Dellgren, G., Stromberg, A. M., Ekberg, H., Hovatta, O., Sylven, C., and Corbascio, M. (2008). Costimulation blockade induces tolerance to HESC transplanted to the testis and induces regulatory T-cells to HESC transplanted into the heart. Stem Cells 26, 1850-1857.

Grinnemo, K. H., Kumagai-Braesch, M., Mansson-Broberg, A., Skottman, H., Hao, X., Siddiqui, A., Andersson, A., Stromberg, A. M., Lahesmaa, R., Hovatta, O., Sylven, C., Corbascio, M., and Dellgren, G. (2006). Human embryonic stem cells are immunogenic in allogeneic and xenogeneic settings. Reprod. Biomed. Online 13, 712-724.

Gutierrez-Dalmau, A., and Campistol, J. M. (2007). Immunosuppressive therapy and malignancy in organ transplant recipients: a systematic review. Drugs 67, 1167-1198.

Hisamatsu-Sakamoto, M., Sakamoto, N., and Rosenberg, A. S. (2008). Embryonic stem cells cultured in serum-free medium acquire bovine apolipoprotein B-100 from feeder cell layers and serum replacement medium. Stem Cells 26, 72-78.

Hovatta, O. (2011). Infectious problems associated with transplantation of cells differentiated from pluripotent stem cells. Semin. Immunopathol. 33, 627-630.

Hovatta, O., Mikkola, M., Gertow, K., Stromberg, A. M., Inzunza, J. Hreinsson, J., Rozell, B., Blennow, E. Andang, M., and Ahrlund-Richter, L. (2003). A culture system using human foreskin fibroblasts as feeder cells allows production of human embryonic stem cells. Hum. Reprod. 18, 1404-1409.

Hussein, S. M., Batada, N. N., Vuoristo, S., Ching, R. W., Autio, R., Narva, E., $\mathrm{Ng}$, S., Sourour, M., Hamalainen, R. Olsson, C., Lundin, K., Mikkola, M. Trokovic, R., Peitz, M., Brustle, O., Bazett-Jones, D. P., Alitalo, K., Lahesmaa, R., Nagy, A., and Otonkoski, T. (2011). Copy number variation and selection during reprogramming to pluripotency. Nature 471, 58-62.

Ilic, D., Stephenson, E., Wood, V., Jacquet, L., Stevenson, D., Petrova A., Kadeva, N., Codognotto, S. Patel, H., Semple, M., Cornwell, G., Ogilvie, C., and Braude, P. (2012). Derivation and feeder-free propagation of human embryonic stem cells under xeno-free conditions. Cytotherapy 14, 122-128.

Kim, K., Doi, A., Wen, B., Ng, K., Zhao, R., Cahan, P., Kim, J., Aryee, M. J., Ji, H., Ehrlich, L. I., Yabuuchi, A., Takeuchi, A., Cunniff, K. C., Hongguang, H., MckinneyFreeman, S., Naveiras, O., Yoon, T. J., Irizarry, R. A., Jung, N., Seita, J., Hanna, J., Murakami, P., Jaenisch, R. Weissleder, R., Orkin, S. H., Weissman, I. L., Feinberg, A. P., and Daley, G. Q. (2010). Epigenetic memory in induced pluripotent stem cells. Nature 467, 285-290.

Kriks, S., Shim, J. W., Piao, J., Ganat, Y. M., Wakeman, D. R., Xie, Z., Carrillo-Reid, L., Auyeung, G., Antonacci, C., Buch, A., Yang, L., Beal, M. F., Surmeier, D. J., Kordower, J. H., Tabar, V., and Studer, L. (2011). Dopamine neurons derived from human ES cells efficiently engraft in animal models of Parkinson's disease. Nature 480, 547-551.

Lechler, R. I., Sykes, M., Thomson, A. W., and Turka, L. A. (2005). Organ transplantation - how much of the promise has been realized? Nat. Med. $11,605-613$.

Li, L., Baroja, M. L., Majumdar, A., Chadwick, K., Rouleau, A., Gallacher, L., Ferber, I., Lebkowski, J., Martin, T., Madrenas, J., and Bhatia, M. (2004). Human embryonic stem cells possess immuneprivileged properties. Stem Cells 22, 448-456.

Li, S. C., and Zhong, J. F. (2009). Twisting immune responses for allogeneic stem cell therapy. World J. Stem Cells $1,30-35$.

Lister, R., Pelizzola, M., Kida, Y. S., Hawkins, R. D., Nery, J. R., Hon, G., Antosiewicz-Bourget, J., O'malley, R., Castanon, R., Klugman, S., Downes, M., Yu, R., Stewart, R., Ren, B., Thomson, J. A., Evans, R. M., and Ecker, J. R. (2011). Hotspots of aberrant epigenomic reprogramming in human induced pluripotent stem cells. Nature $471,68-73$.

Ludwig, T. E., Levenstein, M. E., Jones, J. M., Berggren, W. T., Mitchen, E. R., Frane, J. L., Crandall, L. J., Daigh, C. A., Conard, K. R., Piekarczyk, M. S., Llanas, R. A., and Thomson, J. A. (2006). Derivation of human embryonic stem cells in defined conditions. Nat. Biotechnol. 24, 185-187.

Martin, M. J., Muotri, A., Gage, F., and Varki, A. (2005). Human embryonic stem cells express an immunogenic nonhuman sialic acid. Nat. Med. 11, 228-232.

Mikkelsen, T. S., Hanna, J., Zhang, X., Ku, M., Wernig, M., Schorderet, P., Bernstein, B. E., Jaenisch, R., Lander, E. S., and Meissner, A (2008). Dissecting direct reprogramming through integrative genomic analysis. Nature $454,49-55$.

Ohm, J. E., Mali, P., Van Neste, L. Berman, D. M., Liang, L., Pandiyan, K., Briggs, K. J., Zhang, W., Argani, P., Simons, B., Yu, W., Matsui, W., Van Criekinge, W., Rassool, F. V., Zambidis, E., Schuebel, K. E., Cope, L., Yen, J., Mohammad, H. P., Cheng, L., and Baylin, S. B. (2010). Cancer-related epigenome changes associated with reprogramming to induced pluripotent stem cells. Cancer Res. 70, 7662-7673.

Okita, K., Ichisaka, T., and Yamanaka, S. (2007). Generation of germlinecompetent induced pluripotent stem cells. Nature 448, 313-317.

Okita, K., Nagata, N., and Yamanaka, S. (2011). Immunogenicity of induced pluripotent stem cells. Circ. Res. 109, 720-721.

Pearl, J. I., Lee, A. S., LevesonGower, D. B., Sun, N., Ghosh, Z., Lan, F., Ransohoff, J., Negrin, R. S., Davis, M. M., and Wu, J. C. (2011). Short-term immunosuppression promotes engraftment of embryonic and induced pluripotent stem cells. Cell Stem Cell 8, 309-317.

Pera, M. F. (2011). Stem cells: the dark side of induced pluripotency. Nature 471, 46-47.

Petersen, V. P., Olsen, T. S., KissmeyerNielsen, F., Bohman, S. O., Hansen, H. E., Hansen, E. S., Skov, P. E., and Solling, K. (1975). Late failure or human renal transplants. An analysis 
of transplant disease and graft failure among 125 recipients surviving for one to eight years. Medicine (Baltimore) 54, 45-71.

Rajala, K., Lindroos, B., Hussein, S. M., Lappalainen, R. S., PekkanenMattila, M., Inzunza, J., Rozell, B., Miettinen, S., Narkilahti, S., Kerkela, E., Aalto-Setala, K., Otonkoski, T., Suuronen, R., Hovatta, O., and Skottman, H. (2010). A defined and xeno-free culture method enabling the establishment of clinical-grade human embryonic, induced pluripotent and adipose stem cells. PLOS ONE 5, e10246. doi:10.1371/journal.pone.0010246

Reubinoff, B. E., Pera, M. F., Fong, C. Y., Trounson, A., and Bongso, A. (2000). Embryonic stem cell lines from human blastocysts: somatic differentiation in vitro. Nat. Biotechnol. 18, 399-404.

Rodin, S., Domogatskaya, A., Strom, S., Hansson, E. M., Chien, K. R., Inzunza, J., Hovatta, O., and Tryggvason, K. (2010). Long-term self-renewal of human pluripotent stem cells on human recombinant laminin-511. Nat. Biotechnol. 28, 611-615.
Sidhu, K. S., Walke, S., and Tuch, B. E. (2008). Derivation and propagation of hESC under a therapeutic environment. Curr. Protoc. Stem Cell Biol. Chapter 1, Unit 1A 4.

Swijnenburg, R. J., Schrepfer, S., Govaert, J. A., Cao, F., Ransohoff, K., Sheikh, A. Y., Haddad, M., Connolly, A. J., Davis, M. M., Robbins, R. C., and Wu, J. C. (2008). Immunosuppressive therapy mitigates immunological rejection of human embryonic stem cell xenografts. Proc. Natl. Acad. Sci. U.S.A. 105, 12991-12996.

Takahashi, K., Tanabe, K., Ohnuki, M., Narita, M., Ichisaka, T., Tomoda, K., and Yamanaka, S. (2007). Induction of pluripotent stem cells from adult human fibroblasts by defined factors. Cell 131, 861-872.

Takahashi, K., and Yamanaka, S. (2006). Induction of pluripotent stem cells from mouse embryonic and adult fibroblast cultures by defined factors. Cell 126, 663-676.

Tang, C., Lee, A. S., Volkmer, J. P., Sahoo, D., Nag, D., Mosley, A. R., Inlay, M. A., Ardehali, R., Chavez, S. L., Pera, R. R., Behr, B., Wu, J. C., Weissman, I. L., and Drukker, M. (2011). An antibody against SSEA-5 glycan on human pluripotent stem cells enables removal of teratomaforming cells. Nat. Biotechnol. 29, 829-834.

Thomson, J. A., Itskovitz-Eldor, J., Shapiro, S. S., Waknitz, M. A., Swiergiel, J. J., Marshall, V. S., and Jones, J. M. (1998). Embryonic stem cell lines derived from human blastocysts. Science 282, 1145-1147.

Uchibori, R., Okada, T., Ito, T., Urabe, M., Mizukami, H., Kume, A., and Ozawa, K. (2009). Retroviral vectorproducing mesenchymal stem cells for targeted suicide cancer gene therapy. J. Gene Med. 11, 373-381.

Unger, C., Skottman, H., Blomberg, P., Dilber, M. S., and Hovatta, O. (2008). Good manufacturing practice and clinical-grade human embryonic stem cell lines. Hum. Mol. Genet. 17, R48-R53.

Walsh, P. T., Strom, T. B., and Turka, L. A. (2004). Routes to transplant tolerance versus rejection; the role of cytokines. Immunity 20, 121-131.

Yi, Y., Noh, M. J., and Lee, K. H. (2011). Current advances in retroviral gene therapy. Curr. Gene Ther. $11,218-228$.
Zhao, T., Zhang, Z. N., Rong, Z., and $\mathrm{Xu}, \mathrm{Y}$. (2011). Immunogenicity of induced pluripotent stem cells. Nature 474, 212-215.

Conflict of Interest Statement: The authors declare that the research was conducted in the absence of any commercial or financial relationships that could be construed as a potential conflict of interest.

Received: 16 November 2011; accepted: 26 January 2012; published online: 10 February 2012.

Citation: Forsberg $M$ and Hovatta $O$ (2012) Challenges for the therapeutic use of pluripotent stem derived cells. Front. Physio. 3:19. doi: 10.3389/fphys.2012.00019

This article was submitted to Frontiers in Craniofacial Biology, a specialty of Frontiers in Physiology.

Copyright (C) 2012 Forsberg and Hovatta. This is an open-access article distributed under the terms of the Creative Commons Attribution Non Commercial License, which permits noncommercial use, distribution, and reproduction in other forums, provided the original authors and source are credited. 